\title{
Fluoxetine can make marine organisms unhappy: a study on the sub-lethal effects on marine invertebrates
}

\author{
Pauly, G.F.E.*; Vallim, A. L.; Merguizo, R.A.C.; Daniel, G.; Ramaglia, A. C.; Cortez, F. S.; \\ Miraldo, M. C.; Rojas, E. G.; Cruz, A.C.F. \& Abessa, D. M. S. \\ Instituto de Biociências, Campus do Litoral Paulista, Universidade Estadual Paulista, São Vicente-SP, Brasil
}

Received April 05, 2019; Accept September 10, 2021

\begin{abstract}
The environmental effects caused by selective serotonin reuptake inhibitor drugs have been investigated for marine organisms and coastal ecosystems but are scarce in neotropical organisms. This investigation aimed to evaluate the sublethal effects of fluoxetine on the embryonic development of the sea urchin Echinometra lucunter and the survival and swimming behavior of the brine shrimp Artemia sp. The organisms were exposed to four different concentrations of fluoxetine (30, 300, 3000 and $30000 \mathrm{ng} \mathrm{L}^{-1}$ ) and to a negative control (filtered seawater), following the respective standard testing protocols. We verified a significant reduction of the embryos development to pluteus larvae, starting from $3000 \mathrm{ng} \mathrm{L}^{-1}(54.0 \pm 10.9 \%$ normal larvae), in comparison with the controls $\left(83.5 \pm 3.1 \%\right.$ ). The non-observed effect concentration (NOEC) was estimated at $300 \mathrm{ng} \mathrm{L}^{-1}$, and the lowest observed effect concentration (LOEC) was $3000 \mathrm{ng} \mathrm{L}^{-1}$. In the behavior tests with Artemia sp, no significant adverse effects were reported for mobility, swimming speed and inactivity time. These results show that Fluoxetine can interfere on the development of species like the sea urchin E. lucunter, but short term exposure did not affected the swimming behavior of the brine shrimp Artemia sp. Fluoxetine presents thus a potential to affect marine biota and disrupt the equilibrium of the coastal ecosystems.
\end{abstract}

Key words: Ecotoxicology, marine assessment, sublethal effects, fluoxetine, Artemia sp., Echinometra lucunter.

\section{INTRODUCTION}

The presence of pharmaceuticals and personal care products (PPCPs) in the aquatic ecosystems is of main concern and recently has received attention from scientists, legislators and environmental managers (Kolpin et al., 2002; Sumpter, 2003; Vystavna et al., 2012; giebultowicz \& Nałęcz-Jawecki, 2014). Despite many urban regions and large cities are located on the coastal zone (Martínez et al., 2007), constituting major sources of PPCPs, the adjacent marine and estuarine environments have been little studied for this problem (Gaw et al., 2014). In the developed countries, where wastewater management is well established, the main sources of PPCPs to coastal waters include wastewater treatment plants (WWTPs) (Daughton, 2007), followed by ships, irregular release of domestic sewage, agricultural and livestock residues and aquaculture effluents (Gaw et al., 2014). In countries and regions where wastewaters are not properly collected or treated, the input of sewage to the sea includes diffuse sources, urban drainage and/or its intentional discharge into the sea. Moreover, many coastal cities discharge sewage into the sea throughout sewage outfalls after a pre-conditioning process, which does not remove the contaminants from the effluent.

Once in the aquatic environment, the PPCPs and their metabolites may be found in the water column, sediments, suspended solids and accumulated in the soft tissues of the aquatic biota, such as fish and invertebrates (Ramirez et al., 2009; Birsch et al., 2015; Biel-Maeso et al., 2018). Because PPCPs are bioactive compounds synthesized with therapeutically purposes, and because many metabolic 
pathways are conserved in the most of living organisms, PPCPs may influence non target organisms, affecting their reproduction, growth, sexual differentiation, immune system and behavior (Meguid et al., 2000; Brooks et al., 2006).

In the 1940's decade, Hanfliger and Schindler firstly synthetized the tricyclic antidepressants (TCAs) (Kwon $\&$ Armbrust, 2006), which were used as medicines in the treatment of psychiatric disorders, by acting as serotonin reuptake inhibitors (SRRI) (Sánchez-Argüello et al., 2009) and metabolism inhibitors (Mayberg et al., 2000). Fluoxetine (FLX) is a TCA widely used for the treatment of both adults and children. This compound is the active principle of the commercial drug Prozac ${ }^{\circledR}$, and produce a norfluoxetine, a metabolite that reduce important enzyme activities in vivo, as cytochrome P450 (Goodnick \& Goldstein, 1998). FLX is the most studied TCA, with results indicating acute and chronic toxicity to aquatic organisms (Brooks et al., 2003; Fent et al., 2006; Weinberger \& Kapler, 2014; Luis et al., 2016; Cortez et al., 2019).

Acute effects of FLX were already observed in algae ((Brooks et al., 2003; Johnson et al., 2007), gastropods (Fong \& Molnar, 2013), bivalves (Chen et al., 2015; Cortez et al., 2019) and fish (Brooks et al., 2003; Stanley et al., 2007). In terms of chronic toxicity, increased reproduction was observed in Daphnia magna (Flaherty \& Dodson, 2005), while Ceriodaphnia dubia exhibited reduced reproductive rates (Brooks et al., 2003). Still, little information is available regarding chronic toxicity of FLX (Ansai et al, 2016), with a no-observed effect concentration (NOEC) of $0.47 \mu \mathrm{g} \mathrm{L}^{-1}$ (Nentwig, 2007) and a low-observed effect concentration (LOEC) of $447 \mu \mathrm{g} \mathrm{L}^{-1}$ (Henry et al., 2004). At relevant environmental concentrations, this compound is known to cause behavioral effects in aquatic organisms, as documented for crabs (Peters et al., 2017), amphipods (Bossus et al., 2014), and fish (Barry, 2013), and caused biochemical and citogenotoxic effects in mussels (Cortez et al., 2019) and fish (Duarte et al., 2019), and oxidative stress and reduction of population density in the marine rotifer Brachionus koreanus (Byeon et al., 2020). Most studies were conducted with freshwater organisms (Mennigen et al., 2010; Schultz, et al. 2011; Dzieweczynski \& Hebert, 2012; Kohlert, et al., 2012; Gaw et al., 2014; Lamichhane et al., 2014; Weinberger \& Kapler, 2014; Silva et al., 2015; Kalichak et al., 2016); however, the few studies made with marine organisms suggest a higher sensitivity to FLX (Sverdrup et al., 2002).

Considering that fluoxetine, like as most of contaminants, ends up in the marine environment, the assessment of its toxic effects on the biota is a critical issue, in order to allow the determination of its toxic thresholds, subsidize ecological risk assessments for this compound (Sverdrup et al., 2002) and especially the estimation of maximum acceptable levels in the environment. In this sense, toxicity tests consist of reliable tools to identify and determine the effects of substances on aquatic organisms. Protocols assessing the effects of pollutants on the embryo-larval of invertebrates, such as bivalves and echinoderms, are sensitive and widely accepted and used worldwide (Ghirardini et al., 2001). Similarly, assessing behavioral changes in organisms allow understanding the chances of survival and reproductive success (Anufriieva \& Shadrin, 2014).

This investigation aimed to evaluate the sublethal effects of the fluoxetine to marine organisms, considering the swimming behavior of Artemia sp. and the embryonic development of the sea-urchin Echinometra lucunter.

\section{MATERIAL AND METHODS}

\section{Test substance - Fluoxetine}

The pharmaceutical Fluoxetine (IUPAC name N-methyl3-phenyl-3-[4-(trifluoromethyl)phenoxy]propan-1-amine) (CAS Number 56296-78-7; molecular weight 345.79; purity $\geq 98 \%$; which molecular formula is $\mathrm{C}_{17} \mathrm{H}_{18} \mathrm{~F}_{3} \mathrm{NO}$ ) as well as all other reagents used in this study were purchased from Sigma Aldrich (Steinheim, Germany). FLX is a selective serotonin reuptake inhibitor and consists of an effective substance to treat the symptoms of human depression (O'Shea, 1991). The compound is stable at normal conditions, with a fusion temperature ranging about $158.4-158.9^{\circ} \mathrm{C}$. Its solubility in water is $14 \mathrm{mg} \mathrm{mL}^{-1}$ at $25^{\circ} \mathrm{C}$ and its $\mathrm{pKa}$ is 4.6 (Risley \& Bopp, 1990).

In this investigation, nominal concentrations of FLX were prepared by the direct dilution of FLX in seawater previously filtered through a $45 \mu \mathrm{m}$ pore acetate membrane. Four test concentrations were used $\left(30,300,3000,30000 \mathrm{ng} \mathrm{L}^{-1}\right)$, plus a negative control which consisted of filtered seawater in which FLX was virtually absent $\left(0 \mathrm{ng} \mathrm{L}^{-1}\right)$. The test concentrations were selected based on previous information regarding the environmental levels of FLX and its toxic levels to other species (Mesquita et al., 2011; Franzellitti et al., 2015).

\section{Embryonic development toxicity test - Echinometra lucunter}

In this bioassay, we evaluated the effects of FLX on the development of embryos of the sea urchin Echinometra lucunter after exposing the fertilized eggs to the different chemical concentrations. The tests were conducted following the standard protocol described by ABNT (2012).

Adult individuals of E. lucunter (Linnaeus, 1758) were collected at Palmas island, Guarujá - Brazil (2400'29.47"S - 46 $6^{\circ} 19^{\prime} 30.34^{\prime \prime} \mathrm{W}$ ) and transferred to the laboratory, where spawning was stimulated by osmotic induction (injection of

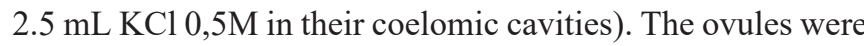
released in a glass beaker containing filtered seawater in an acetate membrane of $0.45 \mu \mathrm{m}$. Prior to in-vitro fertilization, the eggs were examined under microscope for their morphology and viability. The sperm was stored dry in a little beaker kept on ice, until their activation by addition of filtered seawater.

The fertilization was made by adding a 2-ml aliquot of sperm solution into the ovules solution, followed of a gentle agitation for $2 \mathrm{~h}$, in order to allow fecundation. Then, 
sub-samples were examined on microscope to confirm the formation of the fertilization membrane; a viable test should present a minimum of $80 \%$ fertilized eggs. Next, about 500 eggs were introduced in each replicate, which consisted of glass tube tests with $10 \mathrm{ml}$ of test-solutions (i.e. the FLX concentrations or the control). Four replicates were used for each concentration. After about 36 hours (time necessary to the embryos reach the pluteus stage), the test was finished, by the addition of $0.5 \mathrm{~mL}$ tamponed formaldehyde $(10 \%)$ in each replicate. Further, the first 100 embryos of each replicate were examined on microscope, in order to determine the normal development rates and the presence of abnormalities, such as delays, morphological alterations, or absence of development.

\section{Behavioral toxicity test - Artemia sp.}

In the bioassay for identifying behavior effects in adults of brine shrimps (Artemia sp.), 30 healthy males were selected by random from a stock population acquired from a shop. These animals were introduced into glass beakers containing $200 \mathrm{~mL}$ of FLX concentrations (or the control) and exposed for 48 hours, in a static experiment. The physical chemical parameters were controlled during the experiment, as follows: photoperiod of $16 \mathrm{~h}: 8 \mathrm{~h}$ (clear-dark), salinity $35 \pm 1$, and temperature of $25 \pm 2{ }^{\circ} \mathrm{C}$.

At the end of the experiment, 12 animals from each treatment were randomly separated and individually placed in Petri dishes (with mean diameters of $95.7 \pm 4.5 \mathrm{~mm}$ ) containing a water layer enough to allow only the horizontal swimming (about 1-2 mm deep). Then, 6-minutes films were made with each animal, from which the first 5 minutes corresponded to the acclimation period and were discarded from the analyses. In the last minute of each film, the swimming behavior of the animals was evaluated for the following endpoints: mean swimming speed, total distance covered, and inactivity time (Venkateswara Rao et al., 2007). A computer aided tracking video system was employed (Ethovision XT; Noldus Information Technology, Wageningen, Netherlands) to automatize the readings of the respective behaviors.

\section{Statistical Analyses}

The results of the test with sea urchin embryos were firstly used to calculate the inhibition concentration of $50 \%$ development $\left(\mathrm{IC}_{50}\right)$, by using the Trimmed Spearman-Karber method (Hamilton et al., 1977). The data were checked for normality and variance homogeneity by the Shapiro-Wilk's and Levene's tests, respectively. Because the embryonic development data were not normal (Shapiro-Wilks $\mathrm{p}=0.011$ ) and heterocedastic (Levene $\mathrm{p}=0.0007$ ), the results were analyzed by the Kruskal-Wallis test, followed by the Dunn's multiple comparison, in order to calculate the respective NOEC and LOEC.

The behavioral endpoints covered distance and mean swimming speed presented normal distribution and homogeneous variances (Shapiro-Wilks $\mathrm{p}=0.548$ and Levene $\mathrm{p}=0.333$; and Shapiro-Wilks $\mathrm{p}=0.979$ and Levene $\mathrm{p}=0.333$, respectively), thus they were analyzed by one-way analysis of variance (ANOVA) followed by the Tukey's test. For the inactivity time, the data were not normal nor homocedastic $(p<0.05)$, thus they were analyzed by the Kruskal-Wallis teste followed by the Dunn's multiple comparison.

\section{RESULTS}

\section{Embryonic development toxicity test - Echinometra lucunter}

The physical-chemical parameters of the test-solutions are presented in the Table 1, and they remained within the acceptable ranges, according to the test protocol for the species (ABNT, 2012).

The control group presented embryonic development above $80 \%$ (Figure 1), that is the minimum acceptable, according to ABNT (2012). Significant differences were detected among treatments (Kruskal-Wallis; $\mathrm{H}_{(4, \mathrm{~N}=20)}=13.912, \quad \mathrm{p}=0.007$ ). Embryos of E. lucunter exposed to $30,000 \mathrm{ng} \mathrm{L}^{-1}$ exhibited reduced embryonic development rates (Dunn $\mathrm{p}=0.025$ ). The inhibition concentration to $50 \%$ organisms after $36 \mathrm{~h}\left(\mathrm{IC}_{50}-\right.$ $36 \mathrm{~h})$ was calculated as $25,000.9\left(12,884.9\right.$ - 48,745.6) $\mathrm{ng} \mathrm{L}^{-1}$. The LOEC was estimated as $30,000 \mathrm{ng} \mathrm{L}^{-1}$ while the NOEC was $3000 \mathrm{ng} \mathrm{L}^{-1}$.

\section{Behavioral toxicity test - Artemia sp.}

The physical-chemical parameters of the test-solutions are presented in the Table 2, and they remained within the acceptable ranges, according to the test protocol for the species (ABNT, 2012).

In the test evaluating effects on the swimming behavior of Artemia sp., there were no significant differences between

Table 1. Physical-chemical parameters measured at the end of the embryonic experiment with the sea-urchin Echinometra lucunter.

\begin{tabular}{|c|c|c|c|c|c|c|}
\hline $\begin{array}{l}\text { Fluoxetine concentrations } \\
\left(n g L^{-1}\right)\end{array}$ & $\begin{array}{l}\text { Total ammonia } \\
\qquad\left(\mathrm{mg} \mathrm{L}^{-1}\right)\end{array}$ & $\begin{array}{l}\text { Unionized ammonia } \\
\qquad\left(\mathrm{ug} \mathrm{L}^{-1}\right)\end{array}$ & Temperature $\left({ }^{\circ} \mathrm{C}\right)$ & $\mathrm{pH}$ & Salinity & $\begin{array}{c}\text { Dissolved oxygen } \\
\left(\mathrm{mg} \mathrm{L}^{-1}\right)\end{array}$ \\
\hline 0 & 14.13 & 0.25 & $25 \pm 2$ & 7.59 & 35 & 6.60 \\
\hline 30 & 15.57 & 0.30 & $25 \pm 2$ & 7.63 & 35 & 5.40 \\
\hline 300 & 25.42 & 0.46 & $25 \pm 2$ & 7.60 & 35 & 5.20 \\
\hline 3000 & 22.36 & 0.41 & $25 \pm 2$ & 7.61 & 35 & 5.30 \\
\hline 30000 & 17.55 & 0.29 & $25 \pm 2$ & 7.57 & 35 & 4.90 \\
\hline
\end{tabular}




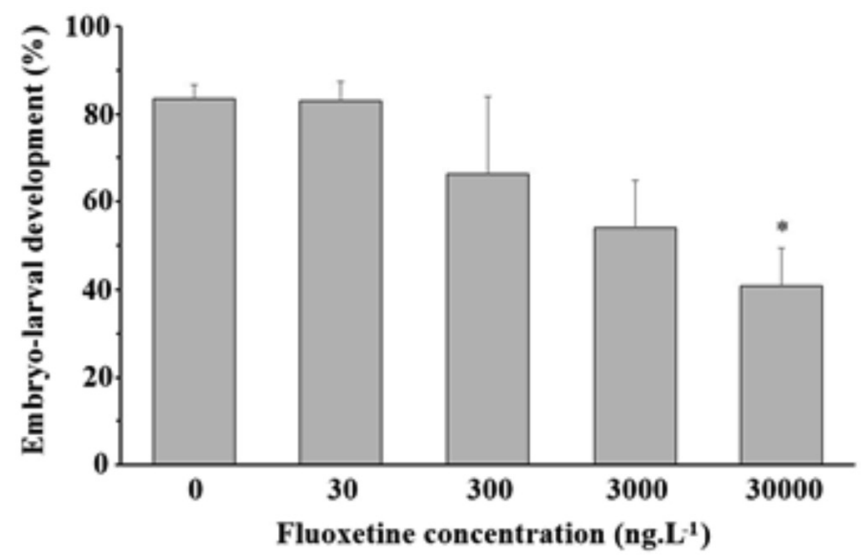

Fig. 1. Percent of normal embryo-larval development of Echinometra lucunter at different concentrations of fluoxetine. ${ }^{*}=$ statistical difference with the control. The error bars show the respective standard deviations.

total covered distances in all concentrations tested (Figure $2 \mathrm{~A}$ - ANOVA; $\left.\mathrm{F}_{4,45}=1,842, \mathrm{p}=0.137\right)$. Regarding the mean swimming speed, no significant differences were detected as well (Figure 2B - ANOVA; $\mathrm{F}_{4,45}=1,838, \mathrm{p}=0.137$ ), as well for the inactivity time (Figure $2 \mathrm{C}-$ Kruskal-Wallis; $\mathrm{H}(4, \mathrm{n}=50)=$ 4.041, $\mathrm{p}=0.399)$.

\section{DISCUSSION}

This study evaluated some biological effects of FLX on marine invertebrates, namely the embryonic development of the sea-urchin E. lucunter and the swimming behavior of the crustacean Artemia sp. Fluoxetine is ranked within the top 20 most threatening pharmaceuticals to the environment, due to its ability to disrupt the endocrine systems of nontarget organisms and the risks associated to its release in the environment (Kumar \& Xagoraraki, 2010).

On the other hand, no differences in the swimming behavior of Artemia sp. were detected (Figure 2) independently of the FLX concentration. According to the literature, other organisms exhibited alterations in their behavior after the exposure to FLX. The estuarine crab Carcinus maenas presented alteration of its locomotion when exposed to $120 \mu \mathrm{g}$ $\mathrm{L}^{-1}$ of FLX (Mesquita et al., 2011); the time required to cover long distances was significantly increased in comparison to the control. De Lange et al. (2006) observed that for the freshwater amphipod Gammarus pulex exposed to 10 and $100 \mathrm{ng} \mathrm{L}^{-1} \mathrm{FLX}$ the locomotion time was $65 \%$ smaller than that exhibited by the control animals. Other studies reported cytotoxic effects of FLX in marine invertebrates, after exposure at $30 \mathrm{ng} \mathrm{L}^{-1}$ (Franzellitti et al., 2014). Moreover, studies reported chronic toxicity in adult vertebrates and invertebrates. Weinberg II \& Klaper (2014) observed a more aggressive behavior and negative effects in the defense and construction of nests in the fathead minnow Pimephales promelas exposed at fluoxetine concentrations $<1$ ug $\mathrm{L}^{-1}$, while Stanley et al. (2007) observed feeding disturbances in the same species. Ding et al. (2017) reported reduction of the enzymatic activity of the acetylcholinesterase (AChE) in D. magna exposed to concentrations up to $5 \mu \mathrm{g} \mathrm{L}^{-1}$ FLX. In studies conducted with

Table 2. Physical-chemical parameters measured at the beginning of the two days exposure to different concentrations of fluoxetine and before the 1 minute shoot of adult males of Artemia sp.

\begin{tabular}{lcccccc}
\hline $\begin{array}{l}\text { Fluoxetine } \\
\text { concentrations (ng L-1) }\end{array}$ & $\begin{array}{c}\text { Total ammonia } \\
\left(\mathrm{mg} \mathrm{L}^{-1}\right)\end{array}$ & $\begin{array}{c}\text { Unionized amônia } \\
\left(\mathrm{ug} \mathrm{L}{ }^{-1}\right)\end{array}$ & Temperature $\left({ }^{\circ} \mathrm{C}\right)$ & $\mathrm{pH}$ & Salinity & $\begin{array}{c}\text { Dissolved oxygen } \\
\left(\mathrm{mg} \mathrm{L}^{-1}\right)\end{array}$ \\
\hline 0 & $<\mathrm{LD}$ & $<\mathrm{LD}$ & $25 \pm 2$ & 7.63 & 35 & 4.70 \\
30 & $<\mathrm{LD}$ & $<\mathrm{LD}$ & $25 \pm 2$ & 7.59 & 34 & 4.80 \\
300 & $<\mathrm{LD}$ & $<\mathrm{LD}$ & $25 \pm 2$ & 8.01 & 35 & 4.90 \\
3000 & $<\mathrm{LD}$ & $<\mathrm{LD}$ & $25 \pm 2$ & 7.77 & 35 & 5.00 \\
30000 & 0,57 & 6,03 & $25 \pm 2$ & 8.17 & 35 & 4.50 \\
\hline
\end{tabular}

LD: detection limit

(a)

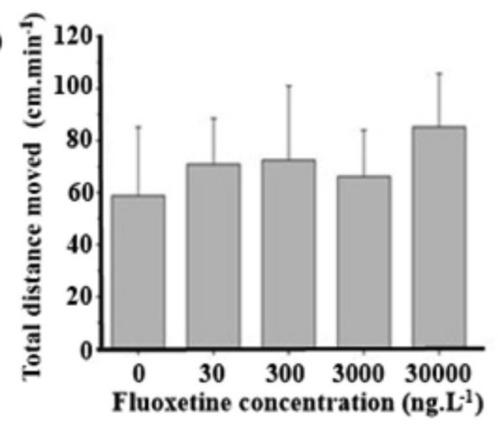

(b)

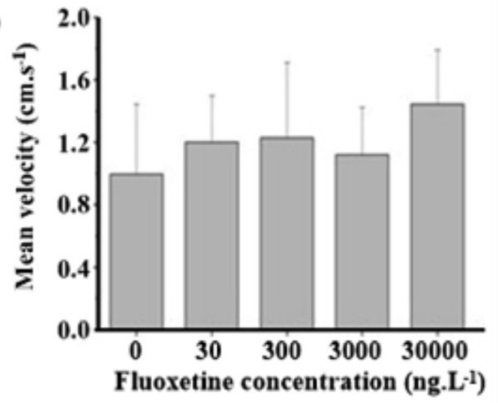

(c)

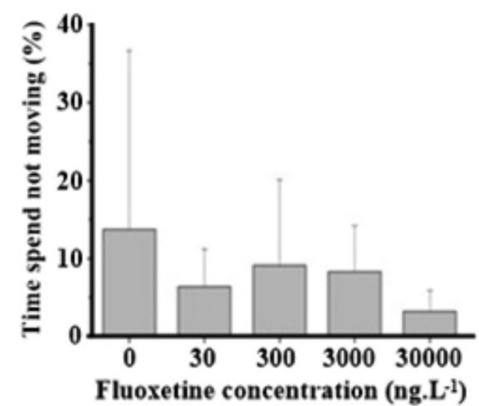

Fig. 2a. Distance traveled by adult individuals of Artemia sp. in 1 minute after two days of exposure to different concentrations of fluoxetine; Fig. 2b. Average speed of adult individuals of Artemia sp. in 1 minute after two days of exposure to different concentrations of fluoxetine; Fig. 2c. Downtime of adult individuals of Artemia sp. in 1 minute after two days of exposure to different concentrations of fluoxetine. Error bars show the respective standard deviations. 
Danio rerio, Chai et al. (2021) observed impairment of cardiac tissue and arrhythmia in organisms exposed to $100 \mathrm{ng} \mathrm{L}^{-1}$ of FLX, while Zindler et al. (2020) reported behavioral changes related with stress, at environmentally relevant concentrations $(2.9 \mathrm{nM})$, and an additive effect when FLX was mixed with its metabolite norfluoxetine.

Comparing the responses of the two species tested, embryos of E. lucunter were more sensitive than Artemia sp. Previous studies reported that adults of Artemia sp. were resistant to environmental changes and chemical substances (Allender et al., 2012; Peixoto et al., 2019). Thus, such tolerance could explain the absence of significant effects of FLX on the behavior of Artemia sp. in the present study. Minguez et al. (2014) showed that nauplii of Artemia salina were more resistant than organisms from other trophic levels, when acute effects were compared.

The results of the present investigation also indicated that toxicity occurred at concentrations higher than those reported in the environment. Fluoxetine concentrations in superficial coastal waters are one order of magnitude lower than the observed toxicity. The mean concentration of FLX in effluents of the WWTP of Seixal (Portugal) was $946 \mathrm{ng}$ $\mathrm{L}^{-1}$ (Salgado et al., 2011), while Birch et al. (2015) found a maximum concentration of $36 \mathrm{ng} \mathrm{L}^{-1}$ in surface waters from an estuary of Sydney, Australia. Other studies conducted in the San Francisco Bay (USA), Mediterranean Sea (Israel) and Pacific Ocean (USA) reported respective maximum and mean concentrations of FLX as $90 \mathrm{ng} \mathrm{L}^{-1}$ and $66 \mathrm{ng} \mathrm{L}^{-1}$ (Nödler et al., 2014). Jiang et al. (2014) reported concentrations of FLX below the detection limit in coastal waters from Taiwan. In Brazil, Cortez et al. (2019) reported concentrations up to $0.58 \mathrm{ng} \mathrm{L}^{-1}$ in coastal waters from the Santos Bay, in the São Paulo State. In the same study, the authors reported enzymatic alterations in soft tissues of the mussel Perna perna exposed to concentrations ranging between 30 and $300 \mathrm{ng} \mathrm{L}^{-1} \mathrm{FLX}$.

Despite the toxic concentrations of FLX obtained in our study are above the environmental concentrations previously reported for coastal surface waters around the world (Jiang et al., 2014; Nödler et al., 2014; Birch et al., 2015), this fact not necessarily indicates lack of environmental risks associated to this compound, because only two species were tested, and tests consisted of short-term exposures. Moreover, the environmental concentrations of FLX in Brazil are unknown, despite the discharge of untreated sewage in most regions. Thus more ecotoxicological studies are required, considering different trophic levels, and especially long-term exposure, in order to provide robust information to determine potential environmental risks associated to the FLX.

Moreover, like other pharmaceuticals, FLX tends to occur in the environment associated with other compounds, especially those present in sewage, such as household products, PPCPs, metals, oil and its derivatives, ammonia and other chemicals (Birch et al., 2015; Ding et al., 2017). Thus, the combination of FLX with other chemicals, in complex mixtures, may produce environmental risks, even if the concentrations are low. In this sense, further studies considering the combined effects of fluoxetine and other chemicals are also required.

\section{ACKNOWLEDGEMENTS}

The authors thank the staff and logistic support from the Center of Investigation on Aquatic Pollution and Ecotoxicology (NEPEA), the Laboratory of Sustainable Aquaculture FINEP, and the Ecotoxicology Laboratory "Professor Caetano Bellibon" from UNISANTA. DMSA thanks CNPq by the PQ fellowship, while ALV, GFE, EGR, MCM, RACM, and ACR thank CAPES (Coordenação de Aperfeiçoamento de Pessoal de Nível Superior) by the support. ACFC and GD thank FAPESP - Fundação de Amparo à Pesquisa de São Paulo (grants \# 2016/02029-4, and \# 2016/04768-9, respectively). FSC thanks CNPq by the financial support (grants \#481358/2012-9 and \#481553/2012-6).

\section{REFERENCES}

ABNT, N., 2012. Ecotoxicologia aquática — Toxicidade crônica de curta duração - Método de ensaio com ouriço-do-mar (Echinodermata: Echinoidea) (Norma Técnica).

ANSAI, S., HOSOKAWA, H., MAEGAWA, S., KINOSHITA, M., 2016. Chronic fluoxetine treatment induces anxiolytic responses and altered social behaviors in medaka, Oryzias latipes. Behav. Brain Res. 303, 126-136.

ANUFRIIEVA, E.V., SHADRIN, N.V., 2014. The swimming behavior of Artemia (Anostraca): new experimental and observational data. Zool. 117, 415-421.

BARRY, M.J., 2013. Effects of fluoxetine on the swimming and behavioural responses of the Arabian killifish. Ecotoxicol. 22, 425-432.

BIEL-MAESO, M., BAENA-NOGUERAS, R.M., CORADAFERNÁNDEZ, C., LARA-MARTÍN, P.A. 2018. Occurrence, distribution and environmental risk of pharmaceutically active compounds (PhACs) in coastal and ocean waters from the Gulf of Cadiz (SW Spain). Sci. Total Environ. 612, 649-659.

BENTO, N.R., 2015. Avaliação Ecotoxicológica dos Fármacos Fluoxetina e Amoxicilina Empregando o Mexilhão Marinho Perna perna (Linnaeus 1758).MSC Dissertação. Universidade Santa Cecília. 46 p.

BYEON, E., PARK, J.C., HAGIWARA, A., HAN, J., LEE, JAESEONG, 2020. Two antidepressants fluoxetine and sertraline cause growth retardation and oxidative stress in the marine rotifer Brachionus koreanus. Aquat. Toxicol. 218, 105337.

BIRCH, G., DRAGE, D., THOMPSON, K., EAGLESHAM, G., MUELLER, J., 2015. Emerging contaminants (pharmaceuticals, personal care products, a food additive and pesticides) in waters of Sydney estuary, Australia. Mar. Pollut. Bull. 97, 56-66.

BOSSUS, M.C., GULER, Y.Z., SHORT, S.J., MORRISON, E.R., FORD, A.T, 2014. Behavioural and transcriptional changes in the amphipod Echinogammarus marinus exposed to two antidepressants, fluoxetine and sertraline. Aquat. Toxicol. 151, 46-56.

BROOKS, B.W., FORAN, C.M., RICHARDS, S.M., WESTON, J., TURNER, P.K., STANLEY, J.K., SOLOMON, K.R., SLATTERY, M., LA POINT, T.W., 2003. Aquatic ecotoxicology of fluoxetine. Toxicol. Lett. 142, 169-183.

BROOKS, B.W., RILEY, T.M., TAYLOR, R.D., 2006. Water quality of effluent-dominated ecosystems: ecotoxicological, hydrological, and management considerations. Hydrobiologia $556,365-379$.

CHAI, T., CUI, F., DI, S., WU, S., ZHANG, Y., WANG, X., 2021. New insights into cardiotoxicity induced by chiral 
fluoxetine at environmental-level: Enantioselective arrhythmia in developmental zebrafish (Danio rerio). Environ. Pollut. 270, 116-182.

CHEN, H., ZHA, J., YUAN, L., WANG, Z., 2015. Effects of fluoxetine on behavior, antioxidant enzyme systems, and multixenobiotic resistance in the Asian clam Corbicula fluminea. Chemosphere 119, 856-862.

CORTEZ, F.S., SOUZA, L.S., GUIMARÃES, L.L., PUSCEDDU, F.H., MARANHO, L.A., FONTES, M.K., MORENO, B.B., NOBRE, C.R., ABESSA, D.M.S., CESAR, A., PEREIRA, C.D.S., 2019. Marine contamination and cytogenotoxic effects of fluoxetine in the tropical brown mussel Perna perna. Mar. Pollut. Bull. 141, 366-372.

DAUGHTON, C.G., 2007. Pharmaceuticals in the environment: Sources and their management. Compr. Anal. Chem. 50, 1-58.

DAUGHTON, C.G., TERNES, T.A., 1999. Pharmaceuticals and personal care products in the environment: agents of subtle change? Environ. Health Perspect. 107, 907.

DE LANGE, H., NOORDOVEN, W., MURK, A., LÜRLING, M., PEETERS, E., 2006. Behavioural responses of Gammarus pulex (Crustacea, Amphipoda) to low concentrations of pharmaceuticals. Aquat. Toxicol. 78, 209-216.

DUARTE, I.A., PAIS, M.P., REIS-SANTOS, P., CABRAL, H.N., FONSECA, V.F., 2019. Biomarker and behavioural responses of an estuarine fish following acute exposure to fluoxetine. Mar. Environ. Res. 147, 24-31.

DZIEWECZYNSKI, T.L., HEBERT, O.L., 2012. Fluoxetine alters behavioral consistency of aggression and courtship in male Siamese fighting fish, Betta splendens. Physiol. \& Behav. 107, 92-97.

FENT, K., WESTON, A.A., CAMINADA, D., 2006. Ecotoxicology of human pharmaceuticals. Aquat. Toxicol. 76, 122-159.

FLAHERTY, C.M., DODSON, S.I., 2005. Effects of pharmaceuticals on Daphnia survival, growth, and reproduction. Chemosphere 61, 200-207.

FONG, P.P., MOLNAR, N., 2013. Antidepressants cause foot detachment from substrate in five species of marine snail. Mar. Environ. Res. 84, 24-30.

FRANZELLITTI, S., BURATTI, S., CAPOLUPO, M., DU, B., HADDAD, S.P., CHAMBLISS, C.K., BROOKS, B.W., FABBRI, E., 2014. An exploratory investigation of various modes of action and potential adverse outcomes of fluoxetine in marine mussels. Aquat. Toxicol. 151, 14-26.

GAW, S., THOMAS, K.V., HUTCHINSON, T.H., 2014. Sources, impacts and trends of pharmaceuticals in the marine and coastal environment. Phil Trans R Soc B 369, 20130572.

GHIRARDINI, A.V., NOVELLI, A.A., LIKAR, B., POJANA, G., GHETTI, P.F., MARCOMINI, A., 2001. Sperm cell toxicity test using sea urchin Paracentrotus lividus Lamarck (Echinodermata: Echinoidea): Sensitivity and discriminatory ability toward anionic and nonionic surfactants. Environ. Toxicol. Chem. 20, 644-651.

GIEBUŁTOWICZ, J., NAŁĘCZ-JAWECKI, G., 2014. Occurrence of antidepressant residues in the sewage-impacted Vistula and Utrata rivers and in tap water in Warsaw (Poland). Ecotoxicol. Environ. Saf. 104, 103-109.

GOODNICK, P.J., GOLDSTEIN, B.J., 1998. Selective serotonin reuptake inhibitors in affective disorders-I. Basic pharmacology. J. Psychopharmacol. (Oxf.) 12, 5-S20.

HAMILTON, M.A., RUSSO, R.C., THURSTON, R.V., 1977. Trimmed Spearman-Karber method for estimating median lethal concentrations in toxicity bioassays. Environ. Sci. Technol. 11, 714-719.

HENRY, T.B., KWON, J., ARMBRUST, K.L., BLACK, M.C., 2004. Acute and chronic toxicity of five selective serotonin reuptake inhibitors in Ceriodaphnia dubia. Environ. Toxicol.
Chem. 23, 2229-2233.

JIANG, J.-J., LEE, C.-L., FANG, M.-D., 2014. Emerging organic contaminants in coastal waters: Anthropogenic impact, environmental release and ecological risk. Mar. Pollut. Bull. 85, 391-399.

JOHNSON, D.J., SANDERSON, H., BRAIN, R.A., WILSON, C.J., SOLOMON, K.R., 2007. Toxicity and hazard of selective serotonin reuptake inhibitor antidepressants fluoxetine, fluvoxamine, and sertraline to algae. Ecotoxicol. Environ. Saf. $67,128-139$.

KALICHAK, F., IDALENCIO, R., ROSA, J.G.S., OLIVEIRA, T.A., KOAKOSKI, G., GUSSO, D., ABREU, M.S., GIACOMINI, A.C.V., BARCELLOS, H.H.A., FAGUNDES, M., PIATO, A.L., BARCELLOS, L.J.G., 2016. Waterborne psychoactive drugs impair the initial development of Zebrafish. Environ. Toxicol. and Pharmacol. 41, 89-94.

KOHLERT, J.G., MANGAN, B.P., KODRA, C., DRAKO, L., LONG, E., SIMPSON, H., 2012. Decreased aggressive and locomotor behaviors in Betta splendens after exposure to fluoxetine. Psychol. Rep. 110, 51-62.

KOLPIN, D.W., FURLONG, E.T., MEYER, M.T., THURMAN, E.M., ZAUGG, S.D., BARBER, L.B., BUXTON, H.T., 2002. Pharmaceuticals, hormones, and other organic wastewater contaminants in US streams, 1999-2000: A national reconnaissance. Environ. Sci. Technol. 36, 1202-1211.

KUMAR, A., XAGORARAKI, I., 2010. Pharmaceuticals, personal care products and endocrine-disrupting chemicals in US surface and finished drinking waters: a proposed ranking system. Sci. Total Environ. 408, 5972-5989.

KWON, J., ARMBRUST, K.L., 2006. Laboratory persistence and fate of fluoxetine in aquatic environments. Environ. Toxicol. Chem. 25, 2561-2568.

LAMICHHANE, K., GARCIA, S.N., HUGGETT, D.B., DEANGELIS, D.L., LA POINT, T.W. Exposures to a selective serotonin reuptake inhibitor (SSRI), sertraline hydrochloride, over multiple generations: Changes in life history traits in Ceriodaphnia dubia. Ecotoxicol. Environ. Saf. 101, 124-130.

LISTER, A., REGAN, C., VAN ZWOL, J., VAN DER KRAAK, G., 2009. Inhibition of egg production in zebrafish by fluoxetine and municipal effluents: a mechanistic evaluation. Aquat. Toxicol. 95, 320-329.

LUIZ, L.G., BARRETO, Â., TRINDADE, T., SOARES, A.M.V.M., OLIVEIRA, M., 2016. Effects of emerging contaminants on neurotransmission and biotransformation in marine organisms An in vitro approach. Mar. Pollut. Bull. 106, 236-244.

MARTÍNEZ, M., INTRALAWAN, A., VÁZQUEZ, G., PÉREZMAQUEO, O., SUTTON, P., LANDGRAVE, R., 2007. The coasts of our world: Ecological, economic and social importance. Ecol. Econ. 63, 254-272.

MAYBERG, H.S., BRANNAN, S.K., TEKELL, J.L., SILVA, J.A., MAHURIN, R.K., MCGINNIS, S., JERABEK, P.A., 2000. Regional metabolic effects of fluoxetine in major depression: serial changes and relationship to clinical response. Biol. Psychiatry 48, 830-843.

MEGUID, M.M., FETISSOV, S.O., VARMA, M., SATO, T., ZHANG, L., LAVIANO, A., ROSSI-FANELLI, F., 2000. Hypothalamic dopamine and serotonin in the regulation of food intake. Nutrition 16, 843-857.

MENNIGEN, J.A., LADO, W.E., ZAMORA, J.M., DUARTEGUTERMAN, P., LANGLOIS, V.S., METCALFE, C.D., CHANG, J.P., MOON, T.W., TRUDEAU, V.L., 2010. Waterborne fluoxetine disrupts the reproductive axis in sexually mature male goldfish, Carassius auratus. Aquat. Toxicol. 100, 354-364. 
MESQUITA, S.R., GUILHERMINO, L., GUIMARÃES, L., 2011. Biochemical and locomotor responses of Carcinus maenas exposed to the serotonin reuptake inhibitor fluoxetine. Chemosphere 85, 967-976.

MINGUEZ, L., DI POI, C., FARCY, E., BALLANDONNE, C., BENCHOUAlA, A., BOJIC, C., COSSU-LEGUILle, C., COSTIL, K., SERPENTINI, A., LEBEL, J.-M., 2014. Comparison of the sensitivity of seven marine and freshwater bioassays as regards antidepressant toxicity assessment. Ecotoxicology 23, 1744-1754.

NENTWIG, G., 2007. Effects of pharmaceuticals on aquatic invertebrates. Part II: The antidepressant drug fluoxetine. Arch. Environ. Contam. Toxicol. 52, 163-170.

NÖDLER, K., VOUTSA, D., LICHA, T., 2014. Polar organic micropollutants in the coastal environment of different marine systems. Mar. Pollut. Bull. 85, 50-59.

O'SHEA, B., 1991. Antidepressants: uses and attitudes among consultant psychiatrists-A questionnaire study. Ir. J. Psychol. Med. 8, 167-170.

PETERS, J.R., GRANEK, E.F., RIVERA, C.E., ROLLINS, M., 2017. Prozac in the water: Chronic fluoxetine exposure and predation risk interact to shape behaviors in an estuarine crab. Ecol. Evol. 7, 9151-9161.

RAMIREZ, A.J., BRAIN, R.A., USENKO, S., MOTTALEB, M.A., O'DONNELL, J.G., STAHL, L.L., WATHEN, J.B., SNYDER, B.D., PITT, J.L., PEREZ-HURTADO, P., 2009. Occurrence of pharmaceuticals and personal care products in fish: results of a national pilot study in the United States. Environ. Toxicol. Chem. 28, 2587-2597.

RISLEY, D.S., BOPP, R.J., 1990. Fluoxetine. Anal. Profiles Drug Subst. 19, 193-219.

SALGADO, R., MARQUES, R., NORONHA, J., MEXIA, J., CARVALHO, G., OEHMEN, A., REIS, M., 2011. Assessing the diurnal variability of pharmaceutical and personal care products in a full-scale activated sludge plant. Environ. Pollut. 159, 23592367.

SÁNCHEZ-ARGÜELLO, P., FERNÁNDEZ, C., TARAZONA, J.V., 2009. Assessing the effects of fluoxetine on Physa acuta (Gastropoda, Pulmonata) and Chironomus riparius (Insecta, Diptera) using a two-species water-sediment test. Sci. Total
Environ. 407, 1937-1946.

SCHULTZ, M.M., PAINTER, M.M., BARTELL, S.E., LOGUE, A., FURLONG, E.T., WERNER, S.L., SCHOENFUSSH, L., 2011. Selective uptake and biological consequences of environmentally relevant antidepressant pharmaceutical exposures on male fathead minnows. Aquat. Toxicol. 104, 38-47.

SILVA, A.C.T. DA, VALENTIN, J.L., VIANNA, M., 2015. Competition for space between fishing and exploratory oil drilling, observed from a drilling platform in the Espirito Santo Basin, Southeastern Brazil. Braz. J. Oceanogr. 63, 33-41.

STANLEY, J.K., RAMIREZ, A.J., CHAMBLISS, C.K., BROOKS, B.W., 2007. Enantiospecific sublethal effects of the antidepressant fluoxetine to a model aquatic vertebrate and invertebrate. Chemosphere 69, 9-16.

SUMPTER, J.R., 2003. Endocrine disruption in wildlife: The future? Pure Appl. Chem. 75, 2355-2360.

SVERDRUP, L.E., FURST, C.S., WEIDEBORG, M., VIK, E.A., STENERSEN, J., 2002. Relative sensitivity of one freshwater and two marine acute toxicity tests as determined by testing 30 offshore E \& P chemicals. Chemosphere 46, 311-318.

VYSTAVNA, Y., HUNEAU, F., GRYNENKO, V., VERGELES, Y., CELLE-JEANTON, H., TAPIE, N., BUDZINSKI, H., LE COUSTUMER, P., 2012. Pharmaceuticals in rivers of two regions with contrasted socio-economic conditions: occurrence, accumulation, and comparison for Ukraine and France. Water. Air. Soil Poll. 223, 2111-2124.

VENKATESWARA RAO, J., KAVITHA, P., JAKKA, N.M., SRIDHAR, V., USMAN, K., 2007. c Artemia salina. Arch. Environ. Contam. Toxicol. 53, 227-232. DOI 10.1007/s00244006-0226-9.

WEINBERGER, J., KAPLER, R., 2014. Environmental concentrations of the selective serotonin reuptake inhibitor fluoxetine impact specific behaviors involved in reproduction, feeding and predator avoidance in the fish Pimephales promelas (fathead minnow). Aquat. Toxicol. 151, 77-83.

ZINDLER, F., STOLL, S., BAUMANN, L., KNOLL, S., HUHN, C., BRAUNBECK, T., 2020. Do environmentally relevant concentrations of fluoxetine and citalopram impair stress-related behavior in zebrafish (Danio rerio) embryos? Chemosphere 261, 127753. 